\title{
Design of Ball Screw Mechanism for Retro Fit of External Grinding Machine
}

\author{
Tarun Kumar ${ }^{1}$, PraveenKumar ${ }^{1}$, Nilesh Kumar Singh ${ }^{1}$, Dr. G. Arun Kumar ${ }^{2}$, \\ Mr.P.N.Gridharan ${ }^{3}$ \\ ${ }^{I}$ Department of Mechanical Engineering, Saveetha School of Engineering, Saveetha University, Chennai -102. \\ ${ }^{2}$ Professor\& Head, Department of Mechanical Engineering, SSE,Saveetha University, Chennai -102. \\ ${ }^{3}$ Asst. Manager, DELPHI-TVS DIESEL SYSTEM LTD, Chennai.
}

\begin{abstract}
To convert the existing grinding machine into a good working machine, a ball screw mechanism is designed and incorporated in the existing grinding machine by retrofitting process. Grinding machine removes material from the work piece by abrasion, which can generate substantial amount of heat. Therefore a coolant System is incorporated to cool the work piece, so that it does not overheat and go out of its tolerance. Grinding practice is a large and diverse area of manufacturing and tool making. It can also rough out large volume of metal quite rapidly. It is usually better suited to the machining of hard materials. Cylindrical grinding is also called center type grinding. It is used in the removing the cylindrical surface and shoulders of the work piece. The five type of cylindrical grinding are outside diameter $(O D)$ grinding. Inside diameter (ID) grinding, plunge grinding, creep feed grinding and center less grinding.It is used in the industries for grinding the nozzle body. The grinding machine can be changed to automatic machine according to one of the latest technologies called PLC's controller. The manually operated grinding machine has some of the in-accuracies and disadvantages compared to new modern CNC grinding machines.Based on the case study of both manual and CNC grinding machine, the manual machine is converted into automatic machine for the better accuracy and efficiency. The main replacement of the machine parts are hydraulic cylinder and stepper motor by ball screw mechanisms and servo motor.
\end{abstract}

Key words: - Retrofitting, Cylindrical Grinding, Servo Drives, Ball Screw

\section{INTRODUCTION}

Grinding is a distinctive technology that uses abrasives or synthetic minerals in loose or bonded form. Grinding is one of most important technologies used by manufacturing today. Grinding is the only method available to engineers to machine and finish ceramics or composite material. In other cases, grinding competes with other technologies and offers the most economical way to produce precision component. As compared with other machining processes, grinding is a costly operation that should be utilized under optimal conditions (6-8).

Grinding is a finishing process used to improve surface finish, abrade hard materials and tighten the tolerance on flat and cylindrical surfaces by removing a small amount of material. In grinding, an abrasive material (6) rubs against the metal part and removes tiny pieces of material. The abrasive material is typically on the surface of a wheel or belt and abrades material in a way similar to sanding. On a microscopic scale (8), the chip formation in grinding is the same as that found in other machining processes. The abrasive action of grinding generates excessive heat so that flooding of the cutting area with fluid is necessary.

\section{RETROFITTING}

Retrofit projects replace or add equipment to existing machine to improve their energy efficiency, increase their output and extend their lifespan, while decreasing emissions. Principally retrofitting describes the measures taken in the manufacturing industry to allow new or updated parts to be fitted to old or out dated assemblies (like blades to wind turbines). The production of retrofit parts is necessary in manufacture when the design of a large assembly is changed or revised. If, after the changes have been implemented, a customer (with an old version of the product) wishes to purchase a replacement part then retrofit parts and assembling techniques will have to be used so that the revised parts will fit suitably onto the older assembly. (6-10)

\subsection{CONSTRUCTION OF THE SySTEM}

In old machine the feed is given by the hydraulic system. But in the retrofit the machine feed is given by the ball screw. Ball screw is one of the latest technologies used in the industry. 


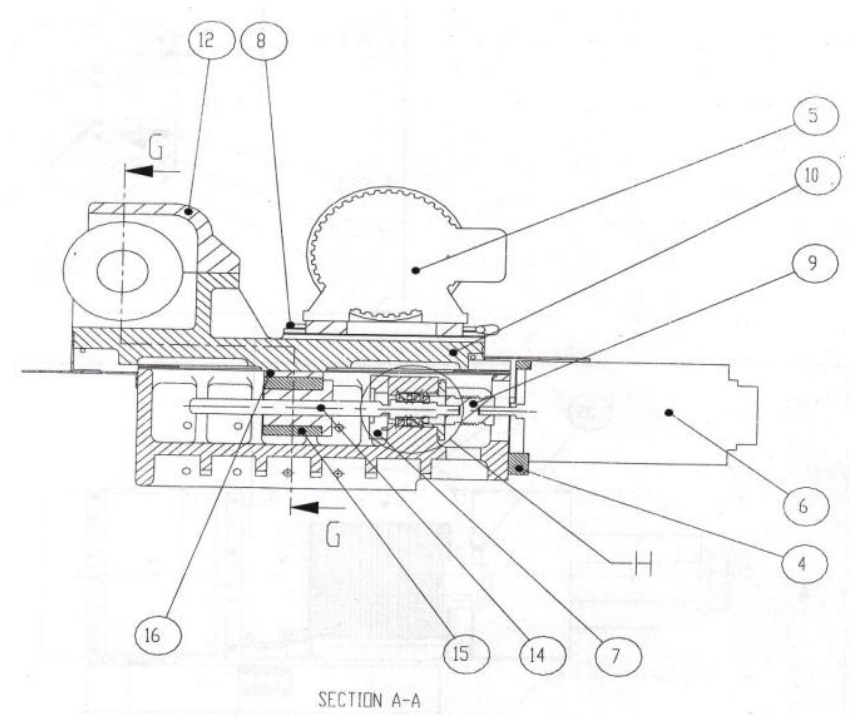

Figure1. Feed Table Sectional View

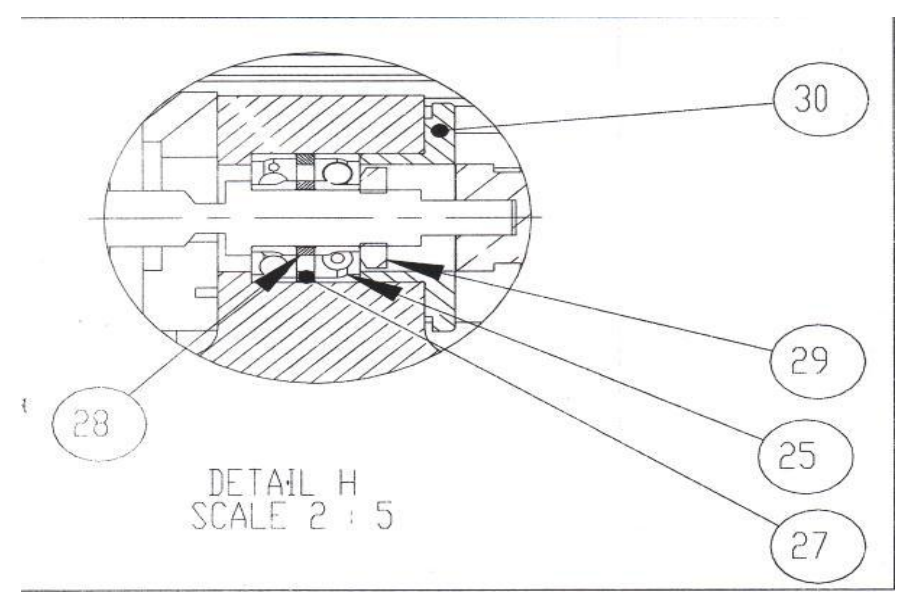

Figure2. Ball Screw Sectional View

The ball screw section view is given above after fitting to the external grinding machine.

\begin{tabular}{|l|l|}
\hline Sr.No & Description \\
\hline 1 & Motor Pulley Bore Ø24 Motor 105/2 Kw/Hp \\
\hline 2 & Belt Guard for Dia Roll \\
\hline 3 & Belt Gurad Cover For Dia Roll \\
\hline 4 & Motor Plate Fanuc \\
\hline 5 & Motor 1.5 Kw/2 Hp, 3000 Rpm \\
\hline 6 & Servo Motor Fanuc Alpha 8ic \\
\hline 7 & Ballscrew Spacer \\
\hline 8 & Motor Clamping Plate \\
\hline 9 & Coup (Dkn100 / 57-19h7), 11473 \\
\hline 10 & Dia Roll Slide \\
\hline 11 & Dia Roll Spindale Sub Assembly \\
\hline 12 & Dia Roll Spindle Mounting Bracket \\
\hline 13 & Dia Roll Housing \\
\hline 14 & B.S Bnfn2505-2.5rgo-29lc3, 112598 \\
\hline 15 & Ball Screw Bracket \\
\hline 25 & Brgfag7005ct P4 \\
\hline 27 & Spacer \\
\hline 28 & Spacer \\
\hline 29 & Lock Nut Km-5 \\
\hline 30 & Cover \\
\hline
\end{tabular}

Table 1. Description of Numerical Notation 


\subsection{TABLE FEED}

Table is without servo axis.Table is fitted with lead screw and reduction gears to adjust the table position manually.For table locking there is one spring plate provided in the front which after table position must be locked.

\subsection{FEED TABLE FRONT VIEW}

After fitting the ball screw mechanism the side view of the feed table is shown below.

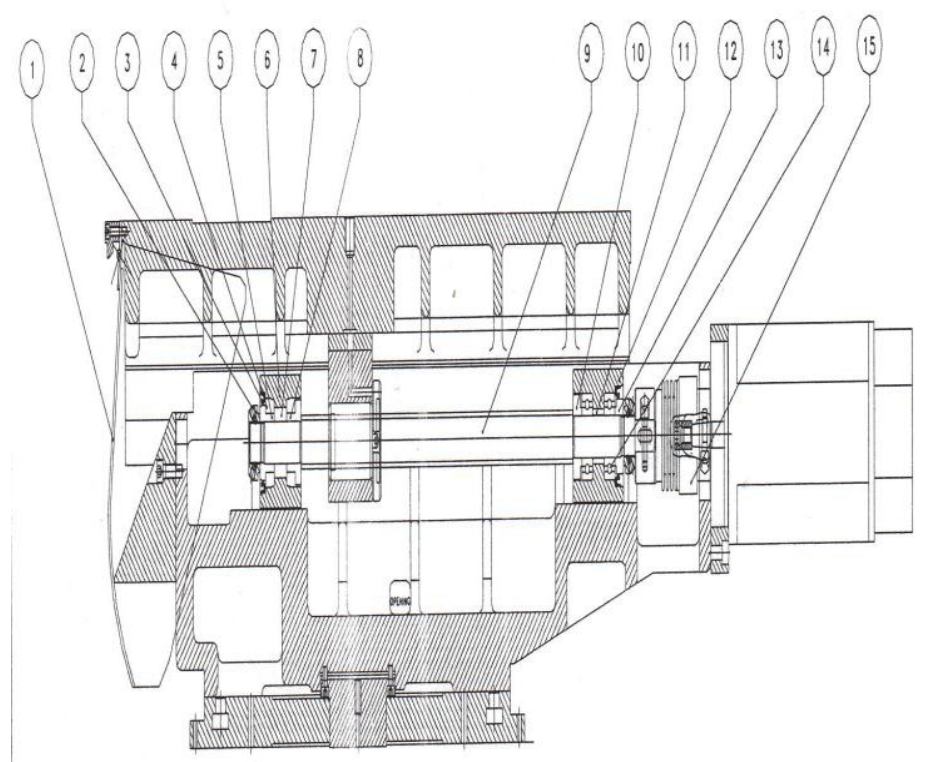

Figure3. Feed Table Front View

\subsection{FEED TABLE SIDE VIEW}

After fitting the ball screw mechanism the side view of the feed table is shown below.

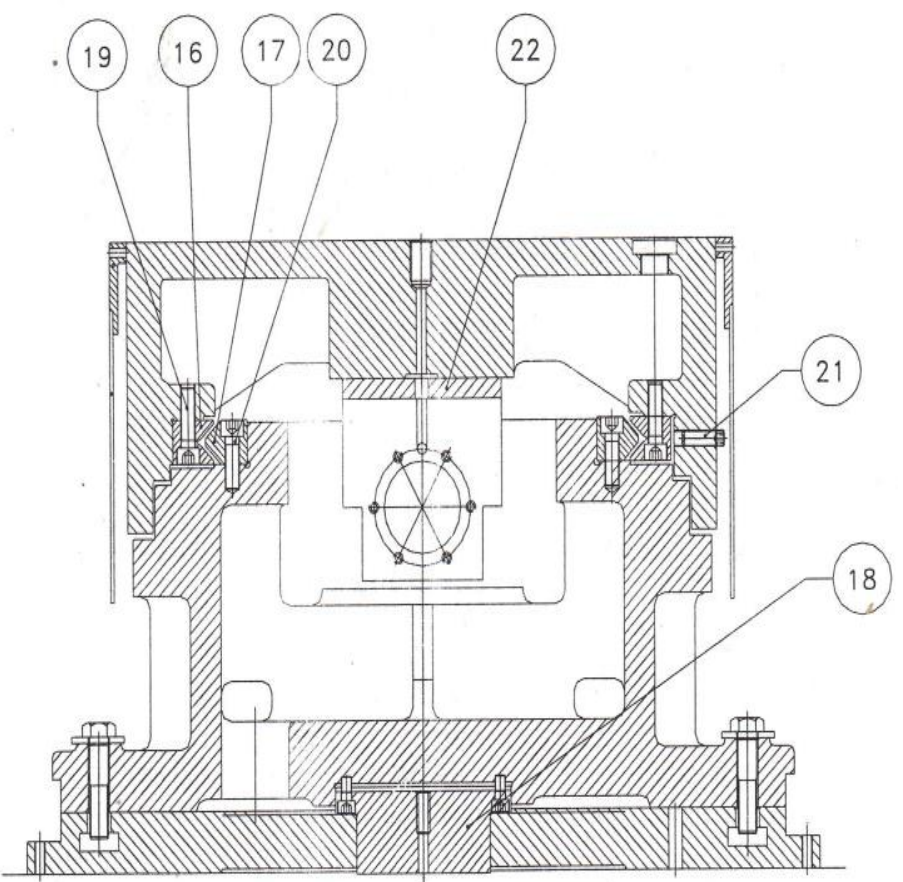

Figure4. Feed Table Front View 


\begin{tabular}{|l|l|}
\hline $\begin{array}{l}\text { Sr. } \\
\mathrm{N} \\
0\end{array}$ & \\
\hline 1 & Description \\
\hline 2 & LOCNT COOLANT GUARD \\
\hline 3 & OIL SEAL 50X68X8/8.5 \\
\hline 4 & THRUST BALL BEARING 51108-Y P5 \\
\hline 5 & SPACER \\
\hline 6 & BEARING BLOCK \\
\hline 7 & NEEDLE ROLLER BEARING NKIS 30/52 INA \\
\hline 8 & SPACER \\
\hline 9 & BALL SCREW DIF 4010-6RRGO-613LC2 \\
\hline 10 & SPACER \\
\hline 11 & SPACER \\
\hline 12 & BEARING BLOCK \\
\hline 13 & SPACER \\
\hline 14 & BALL BEARING 6206 ZZ \\
\hline 15 & SMARTFLEX CPLG 1.932.343, DIA 16 1:10TAP, \\
\hline 16 & DIA24H \\
\hline 17 & LINEAR BEARING N 920625 600 \\
\hline 18 & PIVOT PIN(FOR CARRAGE ROTAION) \\
\hline 19 & ALLEN BOLT 8X30 \\
\hline 20 & ALLEN BOLT 8X25 \\
\hline 21 & GRUB SCREW 8X30 \\
\hline 22 & SPACER \\
\hline
\end{tabular}

Table2.Description of Numerical Notation

\subsection{BOLL SCREW SETTING}

Remove the coupling from motor and replaced make sure that coupling is properly on motor taper shaft. Mount the servo motor on motor plate and clamp the coupling at ball screw end. Make sure that whole assembly of coupling and servo motor is properly done. Assemble the rear cover and tight mounting screw. Move slide to make sure that movement is ok.

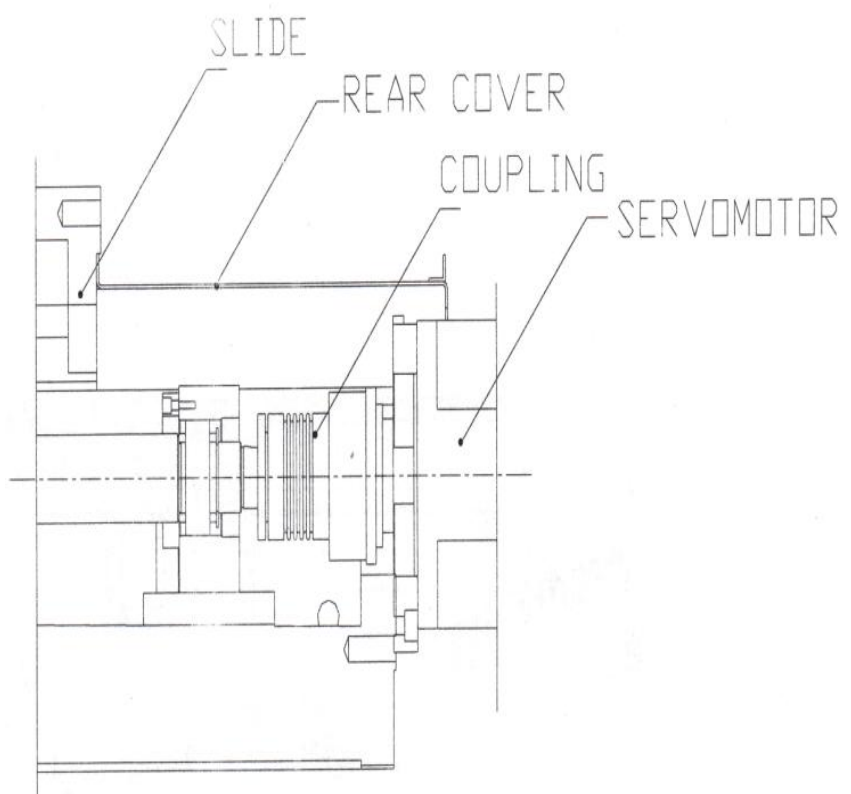

Figure6. Ball Screw Arrangement

\subsection{TECHNICAL SPECIFICATION}

The technical specifications of grinding machine are given below (5). 


\begin{tabular}{|c|c|c|}
\hline $\begin{array}{l}\text { DESCRIPTION } \\
\text { CAPACITY }\end{array}$ & UNIT & $\begin{array}{l}\text { GCE350 } \\
\text { X500 }\end{array}$ \\
\hline Swing Over Table & $\mathrm{mm}$ & 350 \\
\hline $\begin{array}{l}\text { ABC / MAX Grinding } \\
\text { Length }\end{array}$ & $\mathrm{mm}$ & 500 \\
\hline \multicolumn{3}{|l|}{ CARRIAGE (X-AXIS) } \\
\hline Slide Stroke & $\mathrm{mm}$ & 280 \\
\hline Minimum Increment/Pulse & $\mathrm{mm}$ & 0.001 \\
\hline Feed Servomotor Torque & $\mathrm{Nm}$ & 8 \\
\hline \multicolumn{3}{|l|}{ WHEEL HEAD } \\
\hline $\begin{array}{l}\text { Grinding Wheel Size } \\
(\mathrm{OD} \times \mathrm{ID} \times \mathrm{W})\end{array}$ & $\mathrm{mm}$ & $\begin{array}{l}\Phi 500 \times \Phi \\
203.2 \times \\
\Phi 25 / 40\end{array}$ \\
\hline $\begin{array}{l}\text { Spindle Motor Power } \\
\text { (Induction Type) }\end{array}$ & KW & 7.5 \\
\hline Peripheral(Surface) Speed & $\mathrm{m} / \mathrm{s}$ & 45 \\
\hline \multicolumn{3}{|l|}{ WORK HEAD } \\
\hline Canter Taper & No & MT-5 \\
\hline Quill Travel & $\mathrm{rpm}$ & $30-600$ \\
\hline Taper Correction Range & $\mathrm{N} / \mathrm{m}$ & 12 \\
\hline \multicolumn{3}{|l|}{ TAIL STOCK } \\
\hline Canter Taper & No & MT-4 \\
\hline $\begin{array}{l}\text { Spindle Speed (Infinitely } \\
\text { Variable) }\end{array}$ & $\mathrm{mm}$ & 40 \\
\hline Spindle Motor Power & $\mathrm{mm}$ & +0.040 \\
\hline \multicolumn{3}{|l|}{ HYDRAULIC UNIT } \\
\hline Tank Capacity & Ltrs & 40 \\
\hline Motor Power & KW & 0.55 \\
\hline Machine Weight & $\mathrm{Kg}$ & 4000 \\
\hline \multicolumn{3}{|l|}{ CROSS FEED } \\
\hline System Rapid Approach & $\mathrm{mm}$ & 60 \\
\hline Total In Feed On Radius & $\mathrm{mm}$ & 20 \\
\hline In Feed Rate On Die & $\mathrm{Mm} / \mathrm{min}$ & $0-45$ \\
\hline Micro Feed Hand Wheel & $\mathrm{mm}$ & 0.001 \\
\hline Total Power Requirement & $\mathrm{kw}$ & 15 \\
\hline \multicolumn{3}{|c|}{ GROUND FEEED ACCURACY } \\
\hline \multicolumn{3}{|c|}{ ROUNDNESS OF LIVE SPINDLE } \\
\hline Standard & $\mathrm{mm}$ & 0.002 \\
\hline Special & $\mathrm{mm}$ & 0.001 \\
\hline Cylinder/Grinding Length & $\begin{array}{c}\mathrm{mm} / \mathrm{micro} \\
\mathrm{n}\end{array}$ & $0.004 / 500$ \\
\hline \multicolumn{3}{|c|}{ MAXIMUM WORK PIECE WEIGHT } \\
\hline Between Centre & $\mathrm{kg}$ & 80 \\
\hline \multicolumn{3}{|l|}{ MAXIMUM TORQUE } \\
\hline On Live Spindle/Chuck & $\mathrm{kg}$ & 500 \\
\hline Total Weight Of Machine & $\mathrm{kg}$ & 3600 \\
\hline \multicolumn{3}{|c|}{ PACKING CASE DIMENSION } \\
\hline Length & inch & 150 \\
\hline Width & inch & 150 \\
\hline Height & inch & 150 \\
\hline
\end{tabular}

Table3.Technical Specification

3.0 LoAd CALCUlATiON (1-5)

III. MECHANICAL DESIGN

3.1 CYLINDER FORCE $=\mathbf{P} \times \mathbf{A}$

$$
\mathrm{F} 1=0.002 \mathrm{~N}
$$

\subsection{STORKE LENGTH}

STROKE LENGTH $35 \mathrm{MM}=0.035 \mathrm{M}$

$\therefore$ FORCE REQUIRED FOR 35 M.M PISTON MOMENT

$=0.00098 \mathrm{~N}$ FOR 35M.M MOMENT 


\subsection{LOAD REQUIRED FOR GRINDING}

$\mathrm{T}(\mathrm{F} 2)=\Pi \mathrm{NDN} / 60$

$\mathrm{T}=26.17 \mathrm{~N} / \mathrm{M}^{2}$

\subsection{TOTAL FORCE REQUIRED}

$\mathrm{F}=\mathrm{F} 1+\mathrm{F} 2$

$=0.002+26.17$

$\mathrm{F}=26.17 \mathrm{~N} / \mathrm{M}^{2}$

\subsection{FACTOR OF SEAFTY (25\%)}

TOTAL $=26.17+6.54$

$\mathrm{F}=32.71 \mathrm{~N} / \mathrm{M}^{2}(\mathrm{NET} F O R C E)$

3.5 Power Calculation for Servo Drive

We Know That Force REQUIRED For MOMENT

$\mathrm{P} 1=\mathrm{W}$ TAN $(\mathrm{A}+\mathrm{A})$

$\mathrm{P} 1=5.59 \mathrm{~N}$

\subsection{CUTTING (GRINDING) FORCE}

$\mathrm{T}=\Pi \partial \mathrm{N} / 60$

$\mathrm{T}=26 \mathrm{~N} / \mathrm{M}^{2}$

TOTAL POWER $=\mathrm{P} 1+\mathrm{T}$

$\mathrm{P}=\mathrm{P} 1+\mathrm{T}$

$\mathrm{P}=5.59+26$

$\mathrm{P}=31.6 \mathrm{~N}-\mathrm{M}$

\subsection{TORQUE REQURIED FOR BALL SCREW MOMENT}

$\mathrm{T}=\mathrm{P} \times \mathrm{D} / 2$

$\mathrm{T}=354.3 \mathrm{~N} / \mathrm{M}^{2}$

TO FIND R.P.M

$\mathrm{N}=($ SPEED IN M.M/MINT)/(P.C.D)

$=300 / 5=\mathrm{N}=60 \mathrm{R} . \mathrm{P} \cdot \mathrm{M}$

\subsection{ANGULAR SPEED}

$\Omega=6.2 \mathrm{RED} / \mathrm{SEC}$

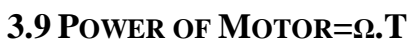

$\mathrm{P}=2197.129 \mathrm{~W}$

3.10 POWER OF MOTOR= 2.1 $\mathrm{KW}$

\section{FLOW CHART FOR SELECTING A BALL SCREW}

\subsection{STEPS FOR SELECTING A BALL SCREW}

When selecting a Ball Screw, it is necessary to make a selection from various angles. The following is a flow chart as a measuring stick for selecting a Ball Screw.(4) 


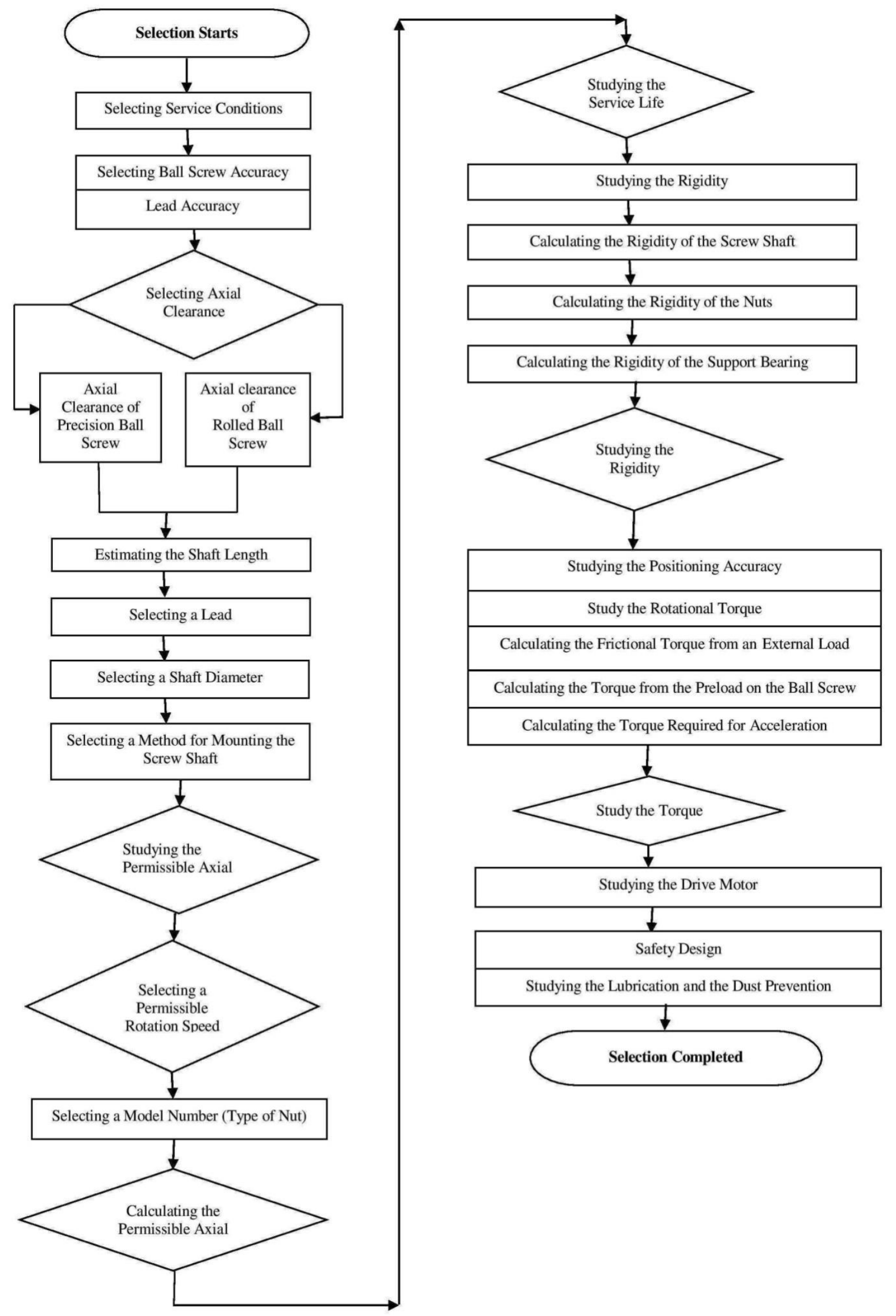


5.1 BEFORE STARTING THE MACHINE

\section{SAFETY}

- Switch On Main Power

- Switch the Isolator

- Switch the Hydraulic

- Switch the Grinding Wheel

- Switch the Mist Collector

\subsection{AFTER STARTING TO CHECK THE MACHINE}

- Release the Emergency Bottom

- Coolant hob\&Position

- D2.5 Ball In Tail Stock

- Dressing Frequency 1/15 Nos

- Home Position

- IVDT Position

- Open Main Air Valve

\subsection{OPERATIONS}

- Select The Mode Change Button To Auto Mode.

- Pick U/P The Nozzle Body From The Input Try.

- Check Must Be Oil Cross/Feed Hole \& Injection Hole Check By Visual.

- Load the component one by one in the loading chute.

- Press Cycle Start Machine.

- After Completion The Component Will Be Collected In Output Tray.

- Take Component By Opening Machine Guard.

- Check Head Diameter.

- If over Size Rework Undersize.

- Next Operation.

VI. CONTROL Plan

\begin{tabular}{|l|l|}
\hline Quality list & Specification \\
\hline Capacity & $30 \mu$ \\
\hline Dim distance Seat chamber & $10.11+0.02 \mathrm{~mm}$ \\
\hline Diameter head & $18.95+0.015 \mathrm{~mm}$ \\
\hline Diameter shaft & $13.885+0-015 \mathrm{~mm}$ \\
\hline
\end{tabular}

\section{CONCLUSION}

Conversion of old machine into working machine to full fill the markets demand. Because now a day's very competition market so after retrofitting of machine the machine running cost will decrease, so the production cost will also decrease. Therefore the company will gate maximum profit.

The accuracy of output product will be increase. After retro fitting the machine the machine running cost will be also decrease. It will provide more comfort to the worker. As compare to CNC machine the retrofitted machine cost is less. The replacement of main machine parts is hydraulic to servo drive with plc control.

Thus the old machine is retrofitted and ready to use. The accuracy and performance of the machine is very god as compare to $\mathrm{CNC}$ machine. 


\section{References}

[1]. R.S Khurmi, J.K Gupta“A Textbook of Machine Design” 2005, Eurasia Publishing House (Pvt.) Ltd.Ram Nagar, New Delhi-110 055 .

[2]. R.K Bansal, “A Textbook Of Strength Of Materials” LaxmiPublications(P) Ltd, Golden House, Daryaganj, New Delhi - 110002, India.

[3]. PSG Collage Of Technology "PSG Design Data book" KalaikathirAchchagam, Coimbatore, Tamil Nadu-641037. India.

[4]. THK "Ball Screw Cat Log” THK GLOBAL, 2010.

[5]. "Micromatic Grinding Machine Manual" Micromatic Grinding Technology Ltd, Ghaziabad, New Delhi- India.

[6]. Konstantios, S., George, T., Stavros, D. (2007) Environmental impact assessment of grind-hardeningprocess. The International Journal of AdvancedManufacturing Technology, vol. 12, no. 5, p. 338-345.

[7]. Chryssolouris, G., Tsirbas, K., Salonitis, K. (2005).An analytical, numerical and experimental approachto grind hardening. Journal of ManufacturingProcess, vol. 7, no. 1, p. 1-9, DOI: 10.1016/S1526- 6125(05)70076-1.

[8]. Zarudi, I., Zhang, L.C. (2002). A revisit to somewheel-work piece interaction problems in surfacegrinding. International Journal of Machine Tools \&Manufacture, vol. 42, no. 8, p. 905-913, DOI:10.1016/S0890-6955(02)00024-X.

[9]. Zhang, L.C. (2007). Grind-hardening of steel surfaces:afoce review. International Journal of AbrasiveTechnology, vol. 1, no. 1, p. 33-36, DOI: 10.1504/IJAT.2007.013847.

[10]. Byrne, G., Dornfeld, D., Inasaki, I., Ketteler, G., Konig,W., Teti, R., 1995. Tool conditionmonitoring (TCM) - the status of research and industrial application. CIRP Annals- Manufacturing Technology 44 (2), 541-567. 